\title{
MSME Growth Analysis Through the Utilization of Start-Up on Demand Service
}

\author{
I Gusti Ayu Purnamawati ${ }^{1, *}$ Gede Adi Yuniarta ${ }^{1}$ I Putu Gede Diatmika ${ }^{1}$
}

\author{
${ }^{1}$ Department of Economic and Accounting, Universitas Pendidikan Ganesha, Singaraja, Indonesia \\ *Corresponding author. Email: igapurnamawati@gmail.com
}

\begin{abstract}
The current development is where start-ups and MSMEs continue to innovate to overcome the country's problems caused by the prolonged COVID-19 outbreak. The emergence of the digital platform can, of course, be a huge market opportunity for the growth of MSMEs, especially in Buleleng Regency. This opportunity is extensively utilized by startup companies that are currently emerging. This study analyzes the development of MSMEs as proxied by an increase in MSME income through start-up on-demand services to support the digitalization of local product marketing in the Buleleng Regency. These variables include the effect of price discounts, payment options, and increased sales prices on start-up on-demand services. Through testing these variables, it will be possible to analyze the growth of MSMEs, which is proxied by the increase in MSME income in the Buleleng Regency. The research subjects are MSME actors in Buleleng Regency with probability sampling for sampling. Data were analyzed using multiple regression. This study revealed a significant influence of price discount variables, payment options, and increasing sales prices on increasing MSME income through the use of start-up on-demand services.
\end{abstract}

Keywords: Growth, Marketing, MSME, Start-Up on-Demand Service.

\section{INTRODUCTION}

Technology brings significant changes in the field of marketing along with the development of online media that are more cost-efficient. The high cost of marketing using conventional methods has resulted in many small companies trying to grow unable to optimize their activities [1]. Start-ups and MSMEs have begun to innovate to address this country's problems amid the Covid-19 pandemic. Especially at this time, Indonesia can become a Southeast Asia that implements digitalization in the economy. It is estimated that by 2025 , the value of digital economy transactions is projected to reach 1.826 trillion rupiahs. However, according to the Ministry of Cooperatives and SMEs, until 2020, only 10.25 million MSMEs are present using the digital platform, which means $16 \%$ of the MSMEs total number in Indonesia [2].

The emergence of the digital platform can, of course, be a huge market opportunity for the growth of MSMEs, especially in Buleleng Regency. This opportunity is extensively utilized by start-up companies that are currently emerging. The start-up itself is a start-up company that tends to be engaged in technology. According to the Investment Coordinating Board, during February 2019, there were 20,070 start-up companies in Indonesia, where these companies were in the on-demand services, financial technology, and e-commerce sectors which experienced the highest growth. Bukalapak is the top-ranked start-up with a score of 85,085 in Indonesia.

In addition to domestic start-ups, Indonesia is also enlivened by the emergence of start-ups from abroad, such as Grab, Shopee, and others. Grab is a company that provides services when users need services provided by the company or often referred to as on-demand applications. Grab is one of the shuttle transportations services, but now Grab has developed and presents several new services. The services provided by Grab are Car, Food, Bike, and Express. Indonesia has reached 126 cities from both big and small towns [3]. When COVID19 hit Indonesia, the challenges to start-up development became unpredictable. Specific economic segments were severely affected, resulting in several large start-ups in the tourism industry being unable to maintain their viability.

On the other hand, e-commerce, educational, fintech start-ups, to on-demand services have undergone enormous changes and developments. The existence of social restrictions during the pandemic impacts the limited activities of the community outside the home, which then also affects fluctuations in sales using ecommerce in Indonesia, especially in the retail sector. Consumers then buy many necessities such as food, beverages, health, and household needs [2]. 
Digital payment systems have experienced unexpected improvements during the COVID-19 pandemic. According to the Payment System Policy Department of Bank Indonesia, this increase is shown by e-commerce transactions in January-September 2020, amounting to 180.74 trillion rupiahs. Indirectly, this encourages a relatively rapid development in digital transformation in Indonesia. The existence of physical distancing rules has an impact on community activities carried out through digital platforms. Transactions using electronic money have increased sharply over the past two years. In 2018, the transaction value, initially 33.67 trillion rupiahs, experienced a spike from 2019 to 2020, namely 145.1 trillion rupiahs to 144.6 trillion rupiahs [4].

A very significant increase in internet usage is the main element that supports e-commerce penetration. Since 2000-2019, Internet users have increased by $1.156 \%$ globally, while growth for Indonesia itself has reached $8.463 \%$, with the number of Internet users ranking fourth (Internetworldstats, 2019). The adoption of e-commerce has become an urgent matter for MSMEs in supporting the economy. However, the Ministry of Communication and Information (2019) confirmed that in 2017, 4.7 million Indonesian MSMEs were using digital platforms (about 7.4\%) of the total MSMEs. Current developments show that only a few MSMEs are adopting e-business and e-commerce amid extraordinary technological growth in the economic field. This number has increased from 9.61 million in 2018 to 104.4\%, which shows the high enthusiasm of MSME actors to use digital access in carrying out their business activities [5].

In 2018, almost 90 per cent of sales in Indonesia were dominated by imported products. The government has made several efforts to support the growth and development of local products, but so far, they have not been optimal. This government support for start-ups to grow big by capturing small opportunities that big businesses don't see, including providing unique products imported directly from farmers and MSMEs in rural areas. So at least, these efforts help farmers, ranchers, and artisans sell their products in the form of raw and finished goods in packaging such as snacks, traditional drinks, kitchen spices, and others.

The food industry is experiencing rapid growth in Buleleng Regency, along with the needs and job opportunities amid economic pressure due to the COVID-19 pandemic; in addition to the increasing public demand for food, this industry continues to develop. Start-up companies use this opportunity to provide delivery services to make it easier for the community and more practical. Based on data from Bank Indonesia, the value of online transactions in the food industry is quite promising, even reaching a deal of 2.313 trillion rupiahs in 2018. One of these start-up companies is Grab, with its service known as Grab food. Ease of payment and time efficiency makes this service very popular with the public.

The partnership between Grab and MSMEs is one of the development strategies to increase Grab food's number of consumers and sales partners. There is a profit-sharing agreement that Grab's sales partners must pay for the sale of their products due to the use of the service. Along with the development of its business, Grab carries out various service innovations to attract the interest of its users. Promotional pricing is also given to users.

Food delivery services are starting to dominate in several cities in Indonesia, including Singaraja, which is categorized as a small city. The selling point of Grab food, which provides food delivery services to consumers, is very much needed in Singaraja. The existence of an agreement on a revenue sharing system between MSMEs and start-ups on demand makes business actors try to increase the price of their products on the application. The product owner sets the selling price to cover production costs and the percentage of profit that the seller wants for the product [6]. This study analyzes the growth of MSMEs as proxied by an increase in MSME income through start-up on-demand services to support the digitalization of local product marketing in the Buleleng Regency. These variables include payment options, price discounts, and sales price increases at startup on-demand services. Through testing these variables, it will be possible to analyze the growth of MSMEs, which is proxied by the rise in MSME income in the Buleleng Regency.

\section{LITERATURE REVIEW}

Theory of Reason Action was developed by [7], is very helpful for researchers in understanding and predicting individual attitudes and behaviour [8]. TRA's ability to predict this makes this theory often used as a theoretical model in information systems. The performance possessed by a person towards a specific behaviour determines the goal to carry out a behaviour, then the plan is also determined by subjective attitudes and norms [9]. There are determining factors in deciding technology acceptance behaviour, including behavioural intention combined with attitudes and norms. The development of the Technology Acceptance Model provides an understanding of the various elements that affect technology acceptance. The theory tries to analyze through a model derivative of Reasoned Action Theory, developed by [10]; [11].

In addition, some factors affect the implementation of a system. These factors, including (1) Perceived usefulness, which is a measure of individual confidence regarding performance improvement supported by the implementation of a system [9], [12], including work effectiveness, increased performance, increased 
productivity, and work efficiency and usefulness. The individual's belief in the service of a system will further encourage him to use it and the opposite situation. (2) Perceived usability is measured when individuals believe that technology systems will free them from the business. Then the perceived use will reduce the effort expended when using it (both time and effort). (3) Intention to use is a person's level as a behavioural tendency in applying technology. According to [13], TAM aims to explore external dimensions impact on attitudes, especially in achieving internal trust, desires, and goals. According to [14], TAM helps observe individual perceptions regarding applying information technology in their activities.

Professionalism in managing the company dramatically affects the development of the company. The primary purpose of the marketing concept is the level of sales volume, meaning that profits will be obtained by selling products to consumers. Thus, increasing sales volume becomes one of the main goals, where sales become an activity in marketing. An increase in sales volume refers to the maximum value consumed by an individual in a period in the hope of getting the same state at the end of the period. thus income is also interpreted as remuneration for the factors of production, while revenue is the amount that producers get in the form of money from the sale of their goods. In line with Keynes's statement, income is identified with changes in the number of factors of production and the ability of each unit to generate income. From a macroeconomic point of view, income is also defined as the value of goods and services produced in one year in a country [15].

Start-up on demand is a newly growing business hoping to lead the market with the original idea by its founder [16]. Start-ups are also included in a company engaged in the creative economy, where there is an opportunity to develop the creative industry sector in a knowledge-based modern economy. This sector is expected to increase income and expand employment opportunities that are greater than the others. [17] states that a start-up on-demand is an organization formed to get new business that repeats itself with market demand as a reference. The same thing was also conveyed by [18], who said that a start-up on-demand is the design of an institution with new products or services under pressure from uncertain conditions. [19] stated that the use of technology in a start-up on-demand with technical problems must be resolved. Start-up on-demand is run to produce innovations in solving problems in people's lives.

A discount by a wholesaler or manufacturer to a retailer at the selling price or catalogue price. Cash discounts are price reductions given to debtors to motivate debtors to make payments within the specified time. These discounts are meant to speed up expenses and thus provide cash flow to the company. Both of these are sometimes used as promotional tools [20]. According to [21], price reductions that have been set are referred to as price discounts because the buyer has agreed on the conditions.

Meanwhile, according to [22], price discounts are an adjustment to the base price for rewards for customers in terms of early bill payments, purchase volume, and purchases out of season. [23] said that discounted prices are price reductions in cash or otherwise. According to [24], the payment system includes rules, institutions, and mechanisms in fund transfer activities about economic activities. For this reason, his understanding is in line with the notion of money as an intermediary in goods, services and financial transactions, which consist of cash and non-cash payment systems. [25] stated that non-cash payments are payment mechanisms without using currency but using paper-based payments and card-based payments. The non-cash payment system is a payment system without money, and it complements the cash payment system.

The selling price is the amount of compensation to get the desired product or service, where the company will set the price of its products in the hope of optimizing profit. According to [26], the selling price impairs monetary units on the goods or services sold. [6] also explained that the price must cover costs, where the selling price is the same as production costs plus a markup. The selling price plays a significant role in obtaining MSME profits. Consistent with the research of [5]; [27]; [28]; [29]. However, different results were presented by [30] and [31], which stated that several other factors affect the income of MSMEs besides the selling price. The price is also related to the attributes that complement a product and become a motive that encourages consumers to shop.

MSMEs through Grab have increased the sales price accompanied by providing promo attractiveness to service users. The price promo policy in discounts is given in cash to attract buyers to buy the products offered. The seller's product price's value to the buyer is determined based on the specified conditions. This price discount is expected to impact increasing sales and income of product sellers [23]. Research by [32] shows that product description, claim settlement, visual pictures, tools in payment and response for the customer are some of the dimensions that influence customer convenience. All of the elements turn out and being preeminent things for customers who buy clothes. In a study conducted by [33] on 183 Lihtuan consumers who buy online, four factors influence customer behaviour: consist of IT technology and skills knowledge, online shopping behaviour, type of culture, price, product information on the website, and type of product. [34] found that significant elements such as convenience and prices/discounts influence online shopping. Meanwhile, ads and recommendations are less effective. 
Based on the background described, this study attempts to analyze the growth of MSMEs as proxied by the increase in MSME income through start-up ondemand services to support the digitalization of local product marketing Buleleng Regency. When detailed, the hypothesis of this research is formulated as: $\mathrm{H}_{1}$ : price discounts affect increasing the income of MSMEs in Buleleng Regency through the use of start-up on-demand services; $\mathrm{H}_{2}$ : Payment options affect increasing MSME income in Buleleng Regency through the use of start-up on-demand services; $\mathrm{H}_{3}$ : The increase in selling prices affects increasing the income of MSMEs in Buleleng Regency through the use of start-up on-demand services.

\section{RESULTS \& DISCUSSION}

The COVID-19 pandemic provides opportunities for MSMEs to develop local products through marketing services by start-up companies. The growth of MSMEs can be measured by increasing their income. The development of MSMEs in the form of increasing their income through the use of start-up on-demand services to support the marketing of local products in Buleleng Regency is the study goal and trying to prove a new theory constructed from the results of previous studies by combining the effects of price discounts, payment options, and price increases selling to increase MSME income. The use of independent and dependent variables includes price discounts, payment options, and an increase in sale price. While the dependent variable: an increase in MSME income.

Table 1. Respondents Data Characteristics

\begin{tabular}{|l|l|r|r|}
\hline Descriptive & \multicolumn{1}{|c|}{ Information } & \multicolumn{1}{c|}{ (\%) } \\
\hline \multirow{3}{*}{ Gender } & Men & 80 & $53 \%$ \\
& Woman & 70 & $47 \%$ \\
\hline \multirow{5}{*}{ Last } & Total & 150 & $100 \%$ \\
\hline Education & Middle & 15 & $10 \%$ \\
& School/Equivalent & 100 & $67 \%$ \\
& High School/Equivalent & 30 & $20 \%$ \\
& Bachelor & 5 & $3 \%$ \\
\hline \multirow{5}{*}{ Age } & Others & 150 & $100 \%$ \\
\hline & Total & 70 & $47 \%$ \\
& $20-30$ & 50 & $33 \%$ \\
& $31-40$ & 25 & $17 \%$ \\
& $41-50$ & 5 & $3 \%$ \\
\hline & $51<$ & 150 & $100 \%$ \\
\hline
\end{tabular}

The research location is in Buleleng Regency. The sample was obtained using probability sampling using proportionate cluster random sampling so that there were 150 MSMEs engaged in the food industry [35]. Data collection methods in this study are observation and interviews. Observation is a non-behavioural observation method to collect secondary data from relevant agencies such as data on the number of MSME actors in the food industry in Buleleng Regency. While, Interviews were conducted with respondents who in this study were SMEs in the food industry in Buleleng Regency.

To be able to achieve the research objectives, the data that has been obtained is analyzed by descriptive qualitative analysis. Descriptive analysis is used to explain quantitative data, variables, research indicators, including defining the results of in-depth interviews conducted in the field to obtain in-depth answers to specific problems that may occur. Quantitative analysis, using hypothesis testing with statistical tests, while data processing and analysis are done through multiple regression equations.

Table 2. Validity

\begin{tabular}{|c|c|c|c|}
\hline Variable & Instrument & $\begin{array}{c}\text { Pearson } \\
\text { Correlation } \\
\end{array}$ & $\begin{array}{l}\text { Cronbach's } \\
\text { Alpha }\end{array}$ \\
\hline \multirow{6}{*}{ Price Discount } & $\mathrm{X} 1.1$ & $0,438^{\star \star}$ & $0,737^{*}$ \\
\hline & $\mathrm{X} 1.2$ & $0,655^{\star *}$ & \\
\hline & $\mathrm{X} 1.3$ & $0,676^{* \star}$ & \\
\hline & $\mathrm{X} 1.4$ & $0,666^{* \star}$ & \\
\hline & $\mathrm{X} 1.5$ & $0,686^{\star \star}$ & \\
\hline & $\mathrm{X} 1.6$ & $0,537^{* *}$ & \\
\hline \multirow{6}{*}{$\begin{array}{l}\text { Payment } \\
\text { Options }\end{array}$} & $\mathrm{X} 2.1$ & $0,683^{\star \star}$ & $0,756^{*}$ \\
\hline & $X 2.2$ & $0,729 * \star$ & \\
\hline & $\times 2.3$ & $0,685^{* *}$ & \\
\hline & $\mathrm{X} 2.4$ & $0,645^{\star \star}$ & \\
\hline & $\mathrm{X} 2.5$ & $0,572^{\star \star}$ & \\
\hline & $\mathrm{X} 2.6$ & $0,524^{* \star}$ & \\
\hline \multirow{6}{*}{$\begin{array}{l}\text { Selling Price } \\
\text { Increase }\end{array}$} & X3.1 & $0,861^{\star \star}$ & $0,799 *$ \\
\hline & $\times 3.2$ & $0,839^{* \star}$ & \\
\hline & $\times 3.3$ & $0,883^{* *}$ & \\
\hline & X3.4 & $0,853^{\star \star}$ & \\
\hline & $\times 3.5$ & $0,751^{\star \star}$ & \\
\hline & X3.6 & $0,624^{* *}$ & \\
\hline \multirow{6}{*}{$\begin{array}{l}\text { Increased } \\
\text { revenue }\end{array}$} & $\mathrm{Y} 1.1$ & $0,616^{\star \star}$ & $0,745^{*}$ \\
\hline & $\mathrm{Y} 1.2$ & $0,628^{* \star}$ & \\
\hline & $\mathrm{Y} 1.3$ & $0,689 * *$ & \\
\hline & $\mathrm{Y} 1.4$ & $0,676^{* \star}$ & \\
\hline & $\mathrm{Y} 1.5$ & $0,534^{* \star}$ & \\
\hline & $\mathrm{Y} 1.6$ & $0,726^{\star *}$ & \\
\hline
\end{tabular}

MSME owners who collaborate with Grab food in the Singaraja area are respondents in this study. The research data was collected through an online questionnaire in a Google Form filled out by 150 MSMEs. Table 1 shows that most of the respondents are dominated by men with a high school education level/equivalent and an average age of 20-30 years. This shows the increased interest of young people in running a business. This research uses a descriptive statistical test with SPSS 21.0 for the Window program. 
Variables $\mathrm{X}_{1}, \mathrm{X}_{2}, \mathrm{X}_{3}, \mathrm{Y}$ have an average value close to the maximum value. It means that all variable has almost the same value. The distribution of respondents' answer choices is on a scale of 4 to 5 . This indicates that most of the respondents agree and strongly agree with the indicators asked. Testing the validity of the data by observing the bivariate correlation between each indicator score and the total construct score, where a significant result is $<0.05$ or $\mathrm{r}$-count $>\mathrm{r}$-table value, the indicator is declared valid. The results of the validity test with bivariate correlation are presented in Table 2 .

The analysis using the Kolmogorov-Smirnov $\mathrm{Z}$ of 0.686 with a significance value (Asymp. Sig. 2-tailed) 0.735 and a significance $>5 \%=$ normally distributed. The VIF value in Table 3 shows that $X_{1}, X_{2}, X_{3}$ (independent variable) is $<10$ and tolerance value is > 0.1 , so there is no multicollinearity. Meanwhile, to determine the presence or absence of heteroscedasticity using the Glejser test. Table 4 shows that the independent variable shows no heteroscedasticity. Likewise, with the significance value of the independent variable $>0.05$.

Table 3. Multicollinearity

\begin{tabular}{|l|c|c|l|}
\hline \multicolumn{1}{|c|}{ Model } & \multicolumn{2}{|c|}{$\begin{array}{c}\text { Collinearity } \\
\text { Statistics }\end{array}$} & \\
\cline { 2 - 4 } & Tolerance & VIF & \\
\hline Price Discount & 0,870 & 1,149 & $\begin{array}{l}\text { No- } \\
\text { Multicollinearity }\end{array}$ \\
\hline Payment Options & 0,838 & 1,193 & $\begin{array}{l}\text { No- } \\
\text { Multicollinearity }\end{array}$ \\
\hline $\begin{array}{l}\text { Selling Price } \\
\text { Increase }\end{array}$ & 0,960 & 1,042 & $\begin{array}{l}\text { No- } \\
\text { Multicollinearity }\end{array}$ \\
\hline
\end{tabular}

Testing of the research model uses multiple linear regression to see the influence of each independent variable on the dependent variable (see Table 5). Calculations obtained through regression analysis are described in the form:

$\mathrm{Y}=3.005+0.404 \mathrm{X}_{1}+0.140 \mathrm{X}_{2}+0.332 \mathrm{X}_{3}$

The information and interpretation:

1. Price discount variable $\left(\mathrm{X}_{1}\right)$ has probability value < 0.05 . Then $\mathrm{H}_{1}$ is accepted; namely, the price discount has a positive and significant effect on increasing income.

2. The payment choice variable $\left(\mathrm{X}_{2}\right)$ has a probability value $<0.05$. Then $\mathrm{H}_{2}$ is accepted. Namely, the choice of payment has a significant effect on increasing income.
Table 4. Heteroscedasticity Test Results

\begin{tabular}{|l|r|l|}
\hline \multicolumn{1}{|c|}{ Model } & Sig. & \multicolumn{1}{c|}{ Information } \\
\hline Price Discount & 0,720 & $\begin{array}{l}\text { Heteroscedasticity does not } \\
\text { occur }\end{array}$ \\
\hline Payment Options 0,783 & $\begin{array}{l}\text { Heteroscedasticity does not } \\
\text { occur }\end{array}$ \\
\hline $\begin{array}{l}\text { Selling Price } \\
\text { Increase }\end{array}$ & 0,854 & $\begin{array}{l}\text { Heteroscedasticity does not } \\
\text { occur }\end{array}$ \\
\hline
\end{tabular}

3. The selling price increase variable $\left(\mathrm{X}_{3}\right)$ has a probability value $<0.05$. Then $\mathrm{H}_{3}$ is accepted. Namely, the increase in selling price has a positive and significant effect on increasing income.

Table 5. Multiple Linear Regression Analysis

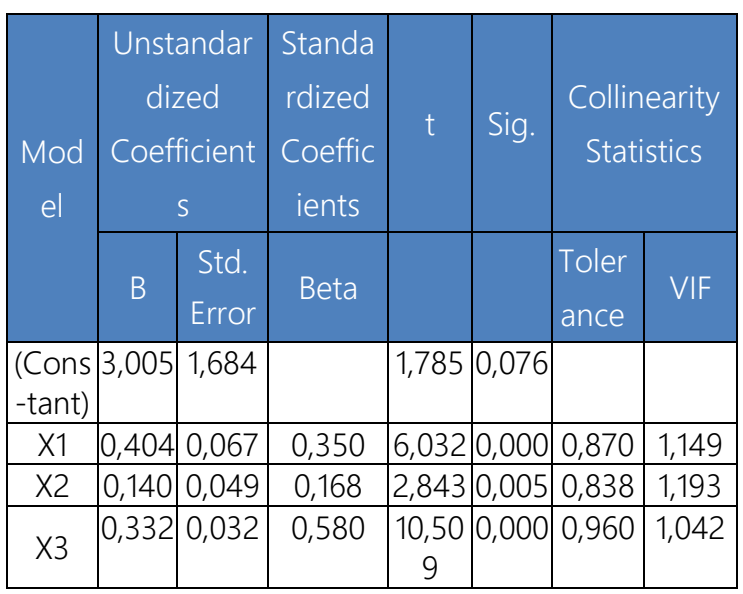

The F statistical test shows the significance value is 0.000 or less than 0.05 (See Table 6). The coefficient of determination is 0.568 , which means $56.4 \%$ of the variation that occurs to high or low income is due to variations in price discounts, payment options, and increased selling prices. In comparison, other variables can cause the remaining $43.6 \%$.

Table 6. F Statistical

\begin{tabular}{|l|l|r|r|r|r|r|}
\hline \multicolumn{2}{|l|}{ Model } & $\begin{array}{r}\text { Sum of } \\
\text { Squares }\end{array}$ & df & $\begin{array}{c}\text { Mean } \\
\text { Square }\end{array}$ & $F$ & Sig. \\
\hline & Regression & 539.501 & 3 & 179.834 & 65.330 & $.000^{\mathrm{b}}$ \\
\hline 1 & Residual & 401.892 & 146 & 2.753 & & \\
\hline & Total & 941.393 & 149 & & & \\
\hline
\end{tabular}

a. Dependent Variable: Y

b. Predictors: (Constant), X3, X1, X2

The discounted price is given to the buyer as a price reduction when the seller offers the product. The discount price provided by the seller is expected to increase sales and offer increased profits to the seller. The theory of TAM expressed by [36] shows that external factors affect beliefs, attitudes, and the purpose of using technology. The discount price offered as the external factors caused by the determination of the discount by the service provider. This discounted price policy will be used as a 
basis for sellers to take a stand to use the technologybased sales system offered by the service provider, in this case, Grab food.

The use of the technology-based sales system offered by Grabfood aims to increase the MSMEs' income, which will impact the profit of MSMEs. The indicators used in this study are the use of price discounts about profit. This benefit measures the number of benefits that MSMEs get when a discounted price policy is implemented by Grab food. The next indicator is the amount of the discount. The amount of the value in question is the discount policy set by Grabfood with different amounts and is related to the profit that can be achieved by the seller when there is a discount policy. Based on theoretical studies and the results of data analysis, the implication is that discount prices positively and significantly influence the increase in income. This study is in line with research conducted by [37] and [38], which state that price discounts significantly affect profit and increase sales volume.

The payment options in this study indicate the choice of a digital-based payment system whose transactions do not use physical money. Bank Indonesia stated that transactions using non-cash payments are currently overgrowing. Throughout 2019, the transaction volume in 2.92 billion and grew by 16,600 times since 2009 . This moment caused Grabfood to offer non-cash prices to every merchant. The goal is to increase non-cash payment users so that customers prioritize purchases from MSMEs that provide non-cash payment systems, with the non-cash payments provided by Grabfood to MSMEs that work together, causing an increase in sales volume, thereby increasing profits that MSME can obtain. Non-cash charges, if associated with the theory of the Technology Acceptance Model, are incorporated in the perceived usefulness factor. Perceived usefulness is a person's level of confidence to implement a technology system to improve its performance. [12] states that if someone believes a technological system can be helpful to improve their performance, the system will be used, and vice versa.

For this reason, collaborating with service providers who offer non-cash payments is believed by the seller to improve their work performance in selling the products being sold. This increase in performance will have an impact on increasing revenue which can increase profit from the seller. For this reason, it can be stated that the choice of payment affects rising income. Consistent with [39] research, where payments using a non-cash system are more favoured by customers, this increases revenue or profit for MSME actors who provide non-cash payment systems in purchasing their products.

The selling price indicated an increase in the number of costs set by the seller. The profit-sharing system found at Grabfood causes an increase in the price of the products sold; an increase in the selling price will affect the rise in income obtained. Based on the technology- based sales system offered by Grabfood, the increase in sales prices is included in the perceived usefulness factor. The increase in sales prices at Grabfood helps increase business productivity; if business productivity increases, of course, the income from the seller will increase. Based on the theory, it can be said that the increase in sales price significantly affects the acquisition of revenue. Then the increase in selling prices has a positive effect on increasing income. The results of this study are also consistent with the research of [40], which states that price increases significantly affect the revenue generated by MSMEs.

\section{CONCLUSION}

This research implies that the increasing price discount will increase the seller's income. The positive relationship is due to customers who take advantage of price discounts to buy products sold, with an increase in customers; of course, an increase in income occurs on the part of MSMEs. In the future, payment options through non-cash payments play an important role in increasing revenue. This study reveals that the choice in transactions using non-cash will increase the income of MSMEs. This is due to the increasing number of users transactions along with the ease of transactions. The existence of noncash transaction payment options will increase the number of customers who buy from the products sold, resulting in an increase in income from MSMEs.

\section{REFERENCES}

[1] M. Lasmadiarta, Facebook Marketing Revolution. Jakarta: PT. Elex Media Komputindo, 2010.

[2] H. Sofia, "Start Up Digital Titik Balik Kebangkitan Desa dan UMKM Indonesia," Antara News, 2020. https://www.antaranews.com/berita/1793469/startup-digital-titik-balik-kebangkitan-desa-dan-umkmindonesia (accessed Feb. 20, 2021).

[3] Grab, "Produk dan Teknologi Terbaru dari Grab," Grab.com 2021. https://www.grab.com/id/press/tech-product/ (accessed Feb. 20, 2021).

[4] R. Y. Adilah, "Pembayaran Digital Naik hingga Rp 180,74 Triliun Selama Pandemi," Liputan 6.com, 2021.

https://www.liputan6.com/bisnis/read/4434266/pe mbayaran-digital-naik-hingga-rp-18074-triliunselama-pandemi (accessed Feb. 20, 2021).

[5] R. Wirdiyanti, "The Impact of E-commerce Adoption on MSMEs Performance and Financial Inclusion (FI) in Indonesia," Jakarta, WP/19/06, 2019. [Online]. Available: https://ojk.go.id/id/datadan-statistik/research/workingpaper/Documents/WP-19-06.pdf. 
[6] Mulyadi, Sistem Akuntansi, 3rd ed. Jakarta: Salemba Empat, 2001.

[7] M. Fishbein and I. Ajzen, Belief, Attitude, Intention and Behavior: An Introduction to Theory and Research. New York: Psychology Press, 1975.

[8] F. D. Davis, R. Bagozzi, and P. R. Warshaw, "User Acceptance of Computer Technology: A Comparison of Two Theoretical Models," Manage. Sci., vol. 35, no. 8, pp. 982-1003, 1989, DOI: 10.1287/mnsc.35.8.982.

[9] F. D. Davis, "Perceived Usefulness, Perceived Ease of Use, and User Acceptance of Information Technology," MIS Q., vol. 13, no. 3, pp. 319-339, 1989, DOI: $10.2307 / 249008$.

[10] I. Ajzen and M. Fishbein, Understanding Attitudes and Predicting Social Behavior. New York: Prentice-Hall, 1980.

[11] L. P. Chin and Z. A. Bin Ahmad, "Perceived Risk As An Extension To TAM Model: Consumers' Intention To Use A Single Platform E-Payment," Aust. J. Basic Appl. Sci., vol. 9, no. 2, pp. 323-330, 2015.

[12] J. Hartono, Metode Penelitian Bisnis: Salah Kaprah dan Pengalaman-Pengalaman. Yogyakarta: BPFE, 2007.

[13] P. Y. A. Putri and G. A. A. A. Parameswara, "Pengaruh Technology Acceptance Model (TAM) Pada Kemampuan Keyakinan Diri Atas Komputer Pengguna Sistem Informasi Akuntansi Di PT Bank Rakyat Indonesia, Tbk. Cabang Gianyar," J. Appl. Manag. Account., vol. 3, no. 2, pp. 227-234, 2019.

[14] V. Venkatesh, J. Y. Thong, and X. Xu, "Consumer Acceptance And Use Of Information Technology: Extending The Unified Theory Of Acceptance And Use Of Technology," MIS Q., vol. 36, no. 1, pp. 175-178, 2012.

[15] Helmalia and Afrinawati, "Pengaruh E-Commerce Terhadap Peningkatan Pendapatan Usaha Mikro Kecil Dan Menengah di Kota Padang," J. Ekon. dan Bisnis Islam, vol. 3, no. 2, pp. 238-246, 2018.

[16] D. S. Kidder, The Startup Playbook: Secrets of the Fastest-Growing Start-ups from Their Founding Entrepreneurs. San Francisco California: Chronicle Books LLC, 2012.

[17] S. Blank, "No Accounting For Startups," Steveblank.com, 2010. https://steveblank.com/2010/02/22/no-accountingfor-startups/ (accessed Feb. 20, 2021).

[18] E. Ries, The Lean Startup. USA: Crown Business, 2011.
[19] G. Avnimelech and M. Teubal, "Venture Capital Start-Up Co-Evolution and the Emergence \& Development of Israel's New High Tech Cluster," Econ. Innov. New Technol., vol. 13, no. 1, pp. 33 60, 2004, DOI: 10.1080/1043859042000156020.

[20] Wikipedia, "Discounts and Allowances," The Free Encyclopedia, 2021 https://en.wikipedia.org/wiki/Discounts_and_allow ances (accessed Apr. 18, 2021).

[21] S. Sigit, Pemasaran Praktis, 3rd ed. Yogyakarta: BPFE, 2008.

[22] P. Kotler and G. Amstrong, Principles of Marketing, 15th ed. England: Pearson Prentice Hall, 2018.

[23] R. Y. . Emor and A. S. Soegoto, "Pengaruh Potongan Harga, Citra Merek, Dan Servicescape Terhadap Keputusan Pembelian Konsumen Indomaret Tanjung Batu," J. Ris. Ekon. Manajemen, Bisnis dan Akunt., vol. 3, no. 2, pp. 738-748, 2015, doi: 10.35794/emba.v3i2.8715.

[24] Bank Indonesia, "Payment System and Rupiah Currency Management," Web Page, 2021. https://www.bi.go.id/en/fungsi-utama/sistempembayaran/default.aspx (accessed Apr. 18, 2021).

[25] Wasiaturrahma, Y. T. Wahyuningtyas, and S. R. Ajija, "Non Cash Payment and Demand for Real Money in Indonesia," J. Econ. Business, Account. Ventur., vol. 22, no. 1, pp. 1-8, 2019, doi: 10.14414/jebav.v22i1.1575.

[26] D. R. Hansen and M. M. Mowen, Management Accounting, 7th Editio. Jakarta: Salemba Empat, 2005 .

[27] M. Milzam, A. Mahardika, and R. Amalia, "Corona Virus Pandemic Impact on Sales Revenue of Micro Small and Medium Enterprises (MSMEs) in Pekalongan City, Indonesia," J. Vocat. Stud. Appl. Res., vol. 2, no. 1, pp. 7-10, 2020, DOI: http://dx.doi.org/10.14710/jvsar.2.1.2020.7-10.

[28] L. A. Reza and N. L. G. E. Sulindawati, "Pengaruh Potongan Harga, Pembayaran Non Tunai, dan Peningkatan Harga Jual pada Startup On Demand Terhadap Perolehan Laba Merchant," J. Akunt. Profesi, vol. 11, no. 1, pp. 126-136, 2020.

[29] F. H. E. Prabowo, "Price Determination Of Chicken Porridge SMEs In Facing Raw Material Cost Fluctuation," J. Manag. Rev., vol. 3, no. 1, pp. 271276, 2019, DOI: 10.25157/jmr.v3i1.1574.

[30] Kurniawan, Kasyim, and Rasyid, "Pengaruh Harga Jual Dan Volume Penjualan Terhadap Pendapatan Pedagang Pengumpul Ayam Potong," J. Univ. Hasannudin, vol. 1, no. 1, pp. 1-8, 2012. 
[31] P. Crisdandi, A. Zukhri, and M. A. Meitriana, "Pengaruh Biaya Pemeliharaan Dan Harga Jual Terhadap Pendapatan Petani Cengkeh Di Desa Tirtasari Pada Tahun 2014," J. Pendidik. Ekon., vol. 5, no. 1, pp. 1-11, 2015, doi: http://dx.doi.org/10.23887/jjpe.v5i1.6397.

[32] V. Masínová and Z. Svandová, "Factors Defining Satisfaction and Loyalty of the Online Shopping Customers within E-Commerce and Cyber Entrepreneurship," in Proceedings of the 9th European Conference on Innovation and Entrepreneurship, 2014, pp. 539-555.

[33] Ž. Baubonienė and G. Gulevičiūtė, "E-Commerce Factors Influencing Consumers" Online Shopping Decision," Soc. Technol. Soc. Technol., vol. 5, no. 1, pp. 74-81, 2015.

[34] H. A. Agyapong, "Exploring the Influential Factors of Online Purchase," Vaasan Ammattikorkeakoulu University, Finland, 2017.

[35] M. Nazir, Metode Penelitian: Edisi Pertama. Jakarta: Ghalia Indonesia, 2003.

[36] M. Davis, A Technology of Acceptance Model for Empirically Testing New-end User Information System: Theory and Result. Massachusetts, USA: Sloan School of Management, Massachusets Institute of Technology, 1986.

[37] Y. Usman, J. J. Sondakh, and M. Y. B. Kalalo, "Analysis the Implementation of Discounts on Sales Level in PT. PLN (Persero) Customer Service Unit Manado Selatan," J. EMBA, vol. 7, no. 3, pp. 44654474, 2019.

[38] D. K. Gauri, B. Ratchford, J. Pancras, and D. Talukdar, "An Empirical Analysis of the Impact of Promotional Discounts on Store Performance," J. Retail., vol. 93, no. 3, pp. 283-303, 2017, DOI: 10.1016/j.jretai.2017.06.001.

[39] V. N. Sari and D. Anggraini, "Factors Affecting Community Interest in the Use of Non-Cash (Digital) Payments," J. Humanit. Soc. Stud., vol. 4, no. 2, pp. 185-191, 2020, DOI: 10.33751/jhss.v4i2.2493.

[40] D. Quirmbach, L. Cornelsen, S. A. Jebb, T. Marteau, and R. Smith, "Effect of Increasing the Price of Sugar-Sweetened Beverages on Alcoholic Beverage Purchases: an Economic Analysis of Sales Data," Epidemiol Community Heal., vol. 72, pp. 324-330, 2018, DOI: 10.1136/jech-2017-209791. 